\title{
Where to submit? Journal choice by construction management authors
}

\author{
Bröchner, Jan, Björk, Bo-Christer. 2008. Where to submit? Journal choice by construction \\ management authors, Construction Management and Economics,
}

Vol 26, No. 7, pp. 739-749

This is the authors' manuscript as accepted for publishing, but before final layout.

\section{Where to submit? Journal choice by construction management authors}

\begin{abstract}
Publishers of academic journals can be seen as service providers to authors, in addition to the traditional role of providers of research results to readers. The purpose of this study was to analyse how author choices of journal in construction management are affected by quality and service perceptions. Seven journals were identified and for each 2006 article, one author email address was extracted. A web based questionnaire was sent to 397 authors and 35\% responded. It was found that there were three journals regularly followed by at least half the respondents. Most of the other four journals have scopes broader than construction management and receive lower scores for characteristics such as impact on researchers. No open access journals were included, and authors in the field of construction management rarely post openly accessible copies of their manuscripts or publications on the web. Author ranking of journals for their next submission is found to be related to general criteria such as academic status, circulation figures and ISI indexation.
\end{abstract}

Keywords: Construction management, research policy, scientific journals

\section{Introduction}

Publishers of academic journals can be seen as service providers to authors, in addition to their traditional role of providers of research results to readers. Authors can be thought of as reacting to a wide set of service characteristics when deciding where to send their manuscripts. Examples of service characteristics not usually taken into account in traditional quality rankings are the speed of publication and how well journals are reaching out to practitioners (Björk and Holmström, 2006). These characteristics should be important not only in fast-moving fields such as biotechnology or IT, where science and commercial exploitation are linked closely.

More than a decade of internet and web experiences has led to new ideas, initiatives and large scale changes in the systems of scholarly publishing. Although there is an ongoing convergence of print and electronic media, it has not resolved the issue of access to everybody's satisfaction. Broader studies of authorial behaviour in general (JISC 2004) indicate that open access copies are available for only about $5-10 \%$ of all journal articles. 
The purpose of this study is to analyse how author choices of journal in construction management are affected by quality and service perceptions. Results are intended to be useful for authors and also for journal editors and publishers who wish to improve their services.

After an overview of theoretical approaches to authorial choice of publication alternatives, the e-mail survey with its web questionnaire will be described. This is followed by the analysis of responses, where journal characteristics associated with submission intent are identified.

\section{Theories of choice}

If authors are assumed to act rationally in the usual economic sense, they should choose a journal for publication of their findings according to where they can expect the highest average value, adjusted for risks and costs. This assumption underlies most of the investigations reviewed by Björk and Holmström (2006), who have found four primary groups of journal characteristics: Infrastructure, Readership, Prestige and Performance. These four groups correspond to measurable characteristics that might exert a direct influence on authorial decisions: CV value of publication, impact on scientists and practitioners, quality of the review process, publication delay, submission rejection risk, service level of journal, technical features of the journal, and author charges. However, there are few studies of author behaviour and author perceptions of service characteristics in fields that lie close to construction management. Ziobrowski and Gibler (2000) made a survey of US academic authors who had published in three leading real estate journals, identifying four factors: (1) fair and efficient editorial process, (2) probability of publication, (3) quality and (4) ranking for promotion and tenure. This is also the structure that they applied later when investigating author choices between real estate journals (Gibler and Ziobrowski, 2002). Through the years, the community of researchers in accounting have shown interest in how their journals function; in a recent empirical contribution, Herron and Hall (2004) rely on a much simpler distinction between author perceptions of journal quality and of feasibility of publishing in a given journal.

The economic rationality is obscured by the apparently erratic pricing of journal subscriptions and the dissociation of authors, readers and those who actually pay for subscriptions (Chesler, 2006). In ecology and also many other fields, there is a strong inverse relationship between ISI impact factors of journals and their subscription prices per article (Bergstrom and Bergstrom, 2006); an explanation is that society publishers tend to have a high proportion of older high impact journals with a large circulation, whereas commercial publishers have many more recently founded low impact journals with low circulation. Higher impact and prestige of low price journals might make authors prefer them, but it is unclear whether this assumption is valid for the field of construction management. A look at the 2007 subscription prices asked for institutional electronic subscriptions in the construction management field reveals a spread of 1:5 for leading journals; the spread is even wider when annual subscription fees are divided by each journal's number of articles in the preceding year. Bundling of subscriptions might reduce the price range, although this effect is hard to estimate.

Open access to articles can be achieved in two ways. The first route is that journals themselves start posting their articles openly on the web, this being run as an open source activity with no common source of funds, or journals recoup their costs by other means than subscriptions, for instance by author charges for publishing. The Lean Construction Journal and the Journal of Information Technology in Construction (ITcon) are examples of the former type. The use of author charges is practised in particular by two biomedical publishers, BioMed Central and Public Library of Science, but this is controversial; an interview survey of British Medical Journal authors reveals that many support the open access concept, while 
prioritizing journal quality for submitting their manuscripts and also disliking charges, unless there is institutional support for paying (Schroter et al., 2005). However, and returning to the issue of the time it takes between submission and publication, it has been argued that the efficient method for reducing delays in top printed journals is to introduce or raise submission fees for authors (Leslie, 2005). Thus the role of fees is complex, independently of the medium relied on for article dissemination.

The second route to open access is that authors publish in the same journals as usual, but themselves post copies of their manuscripts prior to or after peer review on their own web pages, in the institutional repositories of their universities or in subject based repositories such as the ITC Digital Library (itc.scix.net) for construction informatics. Contrary to a widespread belief many publishers allow this practice in their copyright agreements with authors. The Sherpa/Romeo database (www.sherpa.ac.uk/romeo.php) contains information about the policies of all major publishers, and according to it a vast majority of journals allow posting of even the final corrected manuscript after peer review but before final publishers' copyediting and layout.

Another activity with user-generated content and which shows similarities to academic article publishing is open source software development. In particular, the question of why and how software developers choose to participate in open source projects has been approached from other theory bases than article publication. Lerner and Tirole (2005) identify many parallels between open source software development and academic publishing, most obviously related to motivation, but they also point to fundamental differences associated with the incentives to create public goods and concerning access to published work. In their earlier analysis of why programmers engage in open source software development, Lerner and Tirole (2002) grouped the career concern incentive and the ego gratification incentive, stemming from a desire for peer recognition, under the heading of the signalling incentive. This incentive is believed to be stronger the more visible the performance is to the relevant audience, the higher the impact of effort on performance, and the more informative the performance is on talent. In order to understand open source developers, Hertel et al. (2003) have relied on two approaches participation in social movements and individuals' motivation to work in teams. There are similarities and dissimilarities also between scientific publishing and engagement in an open web-based encyclopedia such as Wikipedia. While the process of article publishing is slow, the web-based encyclopedia is quick; while public recognition appears to be essential to authors of scientific articles, there is no strong system of recognition in Wikipedia. Schroer and Hertel (2007) have approached the problem of explaining why there are so many voluntary contributors to Wikipedia and sought explanations by combining social movement research and motivation research based on job characteristics. It is probable that the understanding of the preferences and behaviour of authors, as well as of editors and reviewers, in a field like construction management could be improved by recognizing such non-career sources of motivation.

The "invisible colleges" (Crane, 1972) of a particular research field usually have established ranking orders of the journals in the field, whether these rankings be unofficial or published. These have been based in most cases on an assessment of the rigour of the review process of a journal and the academic quality of its papers. Sporadically, there have been studies of construction management journals. A pioneering study of content, authors and citations to be found in the first decade of articles in Construction Management and Economics was published by Betts and Lansley in 1993, who also analysed the International Journal of Project Management (Betts and Lansley, 1995). Chau (1997) ranked 22 construction management journals according to perceived quality, based on e-mail responses from the CNBR network. More recently, Pietroforte and Stefani (2004) have analysed contents in 
articles published in the ASCE Journal of Construction Engineering and Management, followed by an analysis of both content and contributors in its sister Journal of Management in Engineering (Pietroforte and Aboulezz, 2005). More marginally, Construction Management and Economics, together with International Journal of Project Management, make an appearance in the core list of 562 journals defined in the analysis by Geary and al. (2004) of publications cited in submissions to the Business and Management panel belonging to the 2001 UK Research Assessment Exercise. Recently, Adeli (2007) discussed ISI impact factors for journals in a closely related field, civil and infrastructure engineering research.

Uncritical use of simple bibliometric measures as proxies for research quality has been deplored (Steele et al., 2006), not least for their limited applicability outside the natural sciences (Hicks, 1999), and the need for broader views has been acknowledged in the successive changes in the UK Research Assessment Exercises (Bence and Oppenheim, 2005). At the same time, there is a rising trend in many countries to encourage university faculty to publish more (Australia: McGrail et al., 2006) and to conform to Anglo-American patterns of publication, as in the case of Norway (Kyvik, 2003). Easier web accessibility of journal articles, although in most cases strictly limited to subscribers rather than being freely offered, has contributed to the prominence of international journals as vehicles for scientific advance. However, there are differences between scientific fields in publication patterns as well as in how much effort researchers spend on reading. Tenopir and King (2000) have made extensive longitudinal studies over multiple research fields; they have found that academics report on average 370 hours per year reading and that university based academics read on average 188 articles per year. On the other hand, a study by Björk and Turk (2000) of researchers in construction information technology and construction management showed that academics in these fields browse through or read in detail 107 papers as an average per year, a lower figure. Although there are differences in definitions regarding both what is meant by reading and what is meant by a paper, a discrepancy remains.

\section{Research method}

For the present investigation of author choice, two sets of variables have been selected according to the Björk and Holmström (2006) methodology for benchmarking scientific journals from the submitting author's viewpoint. First there are the general criteria that authors are expected to consider when selecting a journal for submission:

- High academic status

- Likelihood of acceptance

- Large circulation

- Relevant readership

- Short lead time from submission to publication

- Journal articles freely available on the web

- Journal indexed by the ISI

- Level of impact factor (for ISI indexed journals)

- Journal recommendation from author's university.

Next, for questions related to author experiences of particular journals, a reduced list of aspects has been selected: service level, read by researchers, career value, review helpfulness and rejection risk. 
In order to aid the interpretation of the results, especially as to the relative roles of intrinsic and extrinsic author motivation, a set of background variables have also been identified: age, tenure, country, reading habits and web posting habits of authors.

The Björk and Holmström (2006) methodology has been tested initially on construction IT journals and proposes the use of four data collection methods, according to sources and availability:

1. Data openly and directly available in printed issues and from the web sites of publishers. For instance subscription rates of journals.

2. Data available openly but which need further computation. In some journals the submission dates for articles are given in the published articles. From these data the average time from submission to publication can be calculated.

3. Data which can be obtained from publishers. Typical examples would be number of paper issue printed (circulation), usage statistics for web downloads.

4. Asking authors about their experiences with journals and perceptions of various journals. This method is appropriate for investigating author perceptions of for instance journal service levels.

An earlier study by Björk et al. (2005) of construction IT journals combined the first and the second method. The third method is difficult to use for a broader range of indicators, since publishers may be reluctant to provide commercially sensitive data, a problem which manifests itself as low response rates to questionnaires (as experienced by de Marchi and Rocchi, 2001). The present study of journals in the field of construction management and economics relies on the fourth method, asking authors in the field. Other relevant examples of author surveys are those by Chau (1997), McKnight and Price (1999), Gibler and Ziobrowski (2002) as well as an e-mail based survey in accounting by Herron and Hall (2004).

The present survey began by defining the relevant set of journals. Four journals in the field of construction management were chosen initially: Construction Management and Economics (CME); Journal of Construction Engineering and Management (JCEM); Engineering, Construction and Architectural Management (ECAM); Building Research and Information (BRI; in this case, only articles with construction management content). Using Google Scholar for construction management articles in BRI and for all articles in CME and ECAM, while Scopus was relied on for JCEM (where the Google Scholar chronological order is unreliable), for each journal, the five authors with the most cited articles published 2000-2004 were identified. Two of the five most cited CME authors are also among the five most cited ECAM authors; the following two most cited ECAM authors have been brought into the analysis, given a total of twenty authors.

Next, since a main idea of this investigation is to support authors when they are choosing between publication outlets, for each of the twenty authors, their (up to) five other journals with their most cited articles published elsewhere have been identified using Google Scholar and the same time period, 2000-2004. All of these authors had not appeared in a full five other journals, but most of them actually had.

The final criteria for selecting among 41 journals thus identified in addition to the four initially chosen were that at least three of the top five cited authors among the original set of four journals should appear with highly cited articles in the journal; the journal should primarily aim at an academic readership; and that construction management should belong to the core area of the journal. Applying these criteria raises the number of journals from four to seven (see Table 1). Note that the procedure followed here has a slight conservative bias; 
journals that have raised their academic profile recently may fail to meet our citation criterion, which could explain why e.g. the ASCE Journal of Management in Engineering remained outside the set (cf. data provided by Pietroforte and Aboulezz, 2005).

Table 1 Selected journals

\begin{tabular}{|c|c|c|c|}
\hline Journal & Publisher & & $\begin{array}{l}\text { Number } \\
\text { of } \\
\text { articles } \\
(2006)\end{array}$ \\
\hline Automation in Construction (AIC) & Elsevier & & 65 \\
\hline Building Research and Information (BRI) & $\begin{array}{l}\text { Taylor } \\
\text { Francis }\end{array}$ & $\&$ & 44 \\
\hline Construction Innovation (CI) & Emerald & & 16 \\
\hline Construction Management and Economics (CME) & $\begin{array}{l}\text { Taylor } \\
\text { Francis }\end{array}$ & $\&$ & 107 \\
\hline $\begin{array}{l}\text { Engineering, Construction and Architectural Management } \\
\text { (ECAM) }\end{array}$ & Emerald & & 36 \\
\hline International Journal of Project Management (IJPM) & Elsevier & & 72 \\
\hline Journal of Construction Engineering and Management (JCEM) & ASCE & & 135 \\
\hline
\end{tabular}

The second stage was the identification of authors. It is only in 2006 that all seven journals had begun providing e-mail addresses to their corresponding authors, and this implies a new opportunity for investigations. The total number of articles published in 2006 was 475 for the seven journals, and for each article, an e-mail address to the corresponding author was recorded. When there were multiple e-mail addresses and no single corresponding author was identified in the article, the first author with an e-mail address given in the article was chosen; exceptionally, when no e-mail address was given, an author e-mail address was located on the web. After deleting multiple occurrences of names of corresponding authors, 397 author addresses were located, covering all 475 articles. Obviously, the size of a journal matters: academic construction management authors are more likely to be found published in journals with many articles per year (see Table 1) than in the smaller journals, regardless of circulation figures. An even greater range of articles per year is found among top impact management journals, with Management Science having more than ten times as many as are found in Adminstrative Science Quarterly. This should be kept in mind when interpreting the questionnaire responses.

A web questionnaire was designed with 21 questions, including six with five-degree Likert scales. E-mails with links to the questionnaire were sent out in February 2007, and after one reminder, a total of 140 answers had been received, corresponding to a $35 \%$ response rate. Error messages were received for 8\% of the e-mail addresses. Ziobrowski and Gibler (2000) achieved a slightly higher response rate in their study of US real estate authors.

Three of the journals covered by the survey are indexed by ISI: AIC, BRI and JCEM. Table 2 shows the pattern of cross-citations and citations within the same journal (in italics) as far as it can be ascertained from ISI data. The general pattern seen in Table 2 recurs in Table 3, which contains survey data on reading habits of the respondents, matching what can be found in the 
ISI Journal citation reports. This indicates that the respondents are representative of the total population of construction management authors

Table 2 Citations in articles published in 2005

\begin{tabular}{llllllll}
\hline $\begin{array}{l}\text { Citing } \\
\text { journal }\end{array}$ & \multicolumn{2}{l}{ Cited journal } & & & & \\
\cline { 2 - 7 } & AIC & BRI & CI & CME & ECAM & IJPM & JCEM \\
\hline AIC & 65 & 4 & 4 & 8 & 0 & 7 & 67 \\
BRI & 0 & 133 & 0 & 47 & 8 & 12 & 3 \\
JCEM & 13 & 6 & 0 & 94 & 0 & 31 & 488
\end{tabular}

Source: Journal citation reports, ISI.

Table 3 Read both journals regularly [number of respondents]

\begin{tabular}{llllllll}
\hline Journal & \multicolumn{2}{l}{ Journal } & \multicolumn{7}{l}{} \\
\cline { 2 - 7 } & AIC & BRI & CI & CME & ECAM & IJPM & JCEM \\
\hline AIC & 11 & 2 & 2 & 7 & 3 & 3 & 11 \\
BRI & 2 & 19 & 3 & 11 & 4 & 6 & 5 \\
JCEM & 11 & 5 & 5 & 33 & 4 & 7 & 62 \\
\hline
\end{tabular}

\section{Survey results}

Results from the survey are organized here according to the main questions in the web questionnaire.

\section{Respondent profiles}

The personal information provided by the 140 respondents shows that an overwhelming majority (93\%) are university employees, although five respondents are employed by private companies and the remaining five by other organizations outside the university system. Almost half (41\%) of respondents in academia are in a permanent professorial position, and the same percentage applies to those in untenured positions; in addition, $10 \%$ are $\mathrm{PhD}$ students. As data in Table 4 show, there is a good spread geographically with authors from no less than 39 countries being represented; US responses make up 19\% of the total, followed by the UK (14\%), Australia (8\%) and China (7\%). In regional terms, both the continental EU countries (4\%) and Africa (4\%) are comparatively poorly represented. 
Table 4 Respondents per present country of employment

\begin{tabular}{ll}
\hline Country & $\begin{array}{l}\text { Number of } \\
\text { respondents }\end{array}$ \\
\hline United States & 26 \\
United Kingdom & 19 \\
Australia & 11 \\
China & 10 \\
Sweden & 9 \\
Taiwan & 9 \\
Canada & 7 \\
Israel & 4 \\
Singapore & 4 \\
India & 3 \\
Finland & 2 \\
Norway & 2 \\
Pakistan & 2 \\
South Africa & 2 \\
Thailand & 2 \\
United Arab Emirates & 2 \\
Other countries & 26 \\
\hline &
\end{tabular}

\section{Reading habits}

Respondents were asked about the number of scientific articles they either browse through or read in detail per year. The overwhelming majority browsed through 20-199 articles: 21\% browsed through 20-49, 27\% 50-99 and 17\% 100-199 articles. For full reading the majority of respondents belonged to the 10-99 articles range, where 29\% read 10-19, 28\% read 20-49 and $21 \%$ read 50-99. This is in agreement with the earlier study by Björk and Turk (2000) of researchers in construction information technology and construction management.

\section{Criteria for choice of journal}

Respondents were asked what relative weight (on a Likert scale of 1-5, with 5 as the highest score) they attached to a number of factors when choosing where to submit a manuscript. The results are shown in Table 5. Not surprisingly, "high academic status" receives the highest score (4.5 average). But more interestingly number two on the list, "relevant readership" (4.0) is felt to be much more important than large circulation (3.2). Although respondent interpretations of "academic status" and "relevance" may vary, we understand this as showing that the authors care less about reaching a wide audience than being read by the core community of construction management academics, where they hope to have an impact on peers with their results. The fact that many authors seem to care little about articles being "available freely on the web" (2.3), which could increase readership outside the core community, supports this interpretation. 
Table 5 Criteria for choice of journal when submitting a paper

\begin{tabular}{lll}
\hline Criterion & Average score & $\begin{array}{l}\text { Standard } \\
\text { deviation }\end{array}$ \\
\hline High academic status & 4.5 & 0.9 \\
Likelihood of acceptance & 3.3 & 1.1 \\
Large circulation & 3.2 & 1.1 \\
Relevant readership & 4.0 & 1.0 \\
Short lead time from submission to publication & 3.4 & 1.1 \\
Journal articles freely available on the web & 2.3 & 1.2 \\
Journal indexed by the ISI & 3.5 & 1.3 \\
Level of impact factor (for ISI indexed journals) & 3.1 & 1.2 \\
Journal recommendation from author's university & 2.9 & 1.4 \\
\hline 1-5 scales (1 = low, 5=high). & &
\end{tabular}

Two more pragmatic variables affecting the fate of a submission, namely likelihood of acceptance (3.3) and short lead time from submission to final publication (3.4), seem to matter considerably to authors. Nevertheless, this is where there is usually a lack of available statistics and authors have to rely on word of mouth or guesswork.

Finally the factors immediately connected to the reward systems of universities, tenure committees, etc., have medium importance on average. These include ISI indexing (3.5), level of impact factors (3.1) and journal recommendation from the author's university (2.9). It is suggestive that ISI indexing as such is deemed more important than the actual level of the journal impact factor, which would be a better indicator of the quality of a journal. This downplaying of the impact factor may have to do with that, in contrast with most other research fields, few of the journals and conferences where construction management authors publish are indexed by the ISI and also that the impact factors of most indexed journals within this field are low. This is unlike research fields such as management science or information systems, where top journals with high impact factors around 3 - 4 have emerged.

Results in Table 6 indicate that there is a difference in that American authors are more patient; they are also less concerned with whether journals are indexed by the ISI or not. Ziobrowski and Gibler (2000) suspected that tenure might matter, and with our respondents, it seems that those who hold tenured positions in universities tend to write for the select few rather than being concerned with a large circulation; they are also less moved by journal recommendations issued by their university administrations. More unexpectedly, authors who post their manuscripts or articles on the web hold opinions similar to those who do not. 
Table 6 Average criteria scores for US authors, authors with tenure, and authors who post manuscripts or articles on the Web

\begin{tabular}{|c|c|c|c|}
\hline Criterion & US & Tenured & $\begin{array}{l}\text { Post on } \\
\text { Web }\end{array}$ \\
\hline High academic status & 4.7 & 4.5 & 4.5 \\
\hline Likelihood of acceptance & 3.2 & 3.2 & 3.3 \\
\hline Large circulation & 3.4 & $2.9 * *$ & 3.2 \\
\hline Relevant readership & 4.2 & 3.9 & 4.1 \\
\hline $\begin{array}{l}\text { Short lead time from submission to } \\
\text { publication }\end{array}$ & $2.9 * * *$ & 3.4 & 3.3 \\
\hline Journal articles freely available on the web & 2.0 & 2.3 & 2.5 \\
\hline Journal indexed by the ISI & $3.0 * *$ & 3.4 & 3.3 \\
\hline $\begin{array}{l}\text { Level of impact factor (for ISI indexed } \\
\text { journals) }\end{array}$ & 3.0 & 3.0 & 3.3 \\
\hline $\begin{array}{l}\text { Journal recommendation from author's } \\
\text { university }\end{array}$ & 2.7 & $2.6 * * *$ & $3.1^{*}$ \\
\hline
\end{tabular}

$1-5$ scales $(1=$ low, $5=$ high $) ; *=$ significant on the 0.10 level, $* *=$ significant on the 0.05 level, *** significant on the 0.01 level. (Mann-Whitney test, 2-tailed, comparisons with averages for non-US authors, non-tenured, non-posting on Web authors)

Table 7 shows how the nine choice criteria are correlated. Coefficients are mostly in the low range and the general pattern of correlations does not cause any surprise. 
Table 7 Correlations between journal choice criteria

\begin{tabular}{|c|c|c|c|c|c|c|c|c|c|}
\hline \multirow[t]{2}{*}{ Criterion } & \multicolumn{9}{|c|}{ Criterion } \\
\hline & 1 & 2 & 3 & 4 & 5 & 6 & 7 & 8 & 9 \\
\hline $\begin{array}{l}\text { 1. Academic } \\
\text { status }\end{array}$ & 1.00 & & & & & & & & \\
\hline $\begin{array}{l}\text { 2. Acceptance } \\
\text { likelihood }\end{array}$ & -0.05 & 1.00 & & & & & & & \\
\hline $\begin{array}{l}\text { 3. Large } \\
\text { circulation }\end{array}$ & $0.16^{*}$ & 0.09 & 1.00 & & & & & & \\
\hline $\begin{array}{l}\text { 4. Relevant } \\
\text { readership }\end{array}$ & 0.05 & -0.11 & $0.30 * *$ & 1.00 & & & & & \\
\hline $\begin{array}{l}5 . \quad \text { Time } \\
\text { submission- } \\
\text { publication }\end{array}$ & 0.02 & $0.25 * *$ & $0.16^{*}$ & -0.03 & 1.00 & & & & \\
\hline $\begin{array}{l}\text { 6. Articles free } \\
\text { on the Web }\end{array}$ & $-0.19 *$ & $0.31 * *$ & $0.24 * *$ & -0.09 & $0.31 * *$ & 1.00 & & & \\
\hline 7. ISI indexed & $0.29 * *$ & $0.22 * *$ & $0.19 * *$ & 0.10 & $0.22 * *$ & 0.17 & 1.00 & & \\
\hline $\begin{array}{l}\text { 8. ISI impact } \\
\text { factor }\end{array}$ & $0.28 * *$ & $0.23 * *$ & $0.19 * *$ & $0.19 *$ & $0.23 * *$ & 0.08 & $0.65^{* *}$ & 1.00 & \\
\hline $\begin{array}{l}9 . \\
\text { Recommended } \\
\text { journal }\end{array}$ & $0.19 * *$ & $0.14 *$ & 0.14 & -0.06 & $0.14^{*}$ & 0.10 & $0.26^{* *}$ & $0.30 * *$ & 1.00 \\
\hline
\end{tabular}

Nonparametric correlations, Kendall's $\tau: *=$ significant on the 0.05 level (two-tailed), ${ }^{* *}=$ significant on the 0.01 level

Posting copies of manuscripts or articles openly on the web

Authors were asked if they have put up copies of their manuscripts or final versions of conference papers or journal papers on the web. Few authors had done so. The most popular location for manuscripts was the author's own home pages where $18 \%$ had posted at least one manuscript, and for final publications, the institutional repository of the author's university, where again $18 \%$ had posted at least one publication. It appears that $3 \%$ had posted all their manuscripts and also 3\% all their final publications openly on the web.

\section{Readership and impact of the seven journals}

When asked about how often they read each of the seven journals identified in the survey, three of them - CME, JCEM and IJPM - emerged as journals that at least half the respondents follow regularly (Table 8 ). The other four journals, which also cover other topic areas than the central construction management and economics ones, were less regularly followed and unknown to a higher proportion of authors. 
Table 8 Reader habits and impact assessment [\% of responding authors]

\begin{tabular}{|c|c|c|c|c|c|c|c|}
\hline Variable & $\mathrm{AIC}$ & BRI & $\mathrm{CI}$ & CME & ECAM & IJPM & JCEM \\
\hline Not familiar with journal & 42 & 36 & 49 & 11 & 31 & 19 & 16 \\
\hline Read regularly or almost regularly & 23 & 23 & 11 & 57 & 28 & 47 & 66 \\
\hline \multicolumn{8}{|l|}{$\begin{array}{l}\text { Impact on researchers of articles } \\
\text { in the journal }\end{array}$} \\
\hline Don’t know & 51 & 45 & 57 & 21 & 39 & 28 & 26 \\
\hline $\begin{array}{l}\text { For those who know: } \\
\text { High, or almost high (4-5 on } \\
\text { the } \\
\text { 5-degree scale) }\end{array}$ & 48 & 46 & 20 & 81 & 49 & 61 & 86 \\
\hline \multicolumn{8}{|l|}{$\begin{array}{l}\text { Career value of publishing in the } \\
\text { journal }\end{array}$} \\
\hline Don't know & 48 & 44 & 54 & 21 & 38 & 27 & 26 \\
\hline $\begin{array}{l}\text { For those who know: } \\
\text { High, or almost high (4-5 on } \\
\text { the } \\
\text { 5-degree scale) }\end{array}$ & 47 & 49 & 31 & 73 & 55 & 60 & 85 \\
\hline
\end{tabular}

Across journals, there is a broad similarity in the number of respondents who are familiar or unfamiliar with the impact and career value of choosing a particular journal.

\section{Assessing service levels}

When respondents assess the level of service offered by a publisher or the helpfulness of the review process for submitted articles, we can assume that opinions are based on their own experiences or those of close colleagues. This is probably why the "don't know" percentages are higher in Table 9 than in Table 8. 
Table 9 Assessments of service level and review process [\% of responding authors]

\begin{tabular}{|c|c|c|c|c|c|c|c|}
\hline Service level and review process & $\mathrm{AIC}$ & BRI & $\mathrm{CI}$ & $\mathrm{CME}$ & ECAM & IJPM & JCEM \\
\hline \multicolumn{8}{|l|}{ Publisher service level } \\
\hline Don't know & 67 & 67 & 77 & 33 & 59 & 53 & 41 \\
\hline $\begin{array}{l}\text { For those who know the } \\
\text { journal: } \\
\text { High, or almost high (4-5 on } \\
\text { the } \\
5 \text {-degree scale) }\end{array}$ & 52 & 60 & 38 & 79 & 42 & 61 & 57 \\
\hline \multicolumn{8}{|l|}{ Helpfulness of review process } \\
\hline Don’t know & 67 & 65 & 78 & 32 & 57 & 48 & 39 \\
\hline $\begin{array}{l}\text { For those who know: } \\
\text { High, or almost high (4-5 on } \\
\text { the } \\
\text { 5-degree scale) }\end{array}$ & 57 & 57 & 35 & 77 & 48 & 57 & 74 \\
\hline
\end{tabular}

The median time from submission to publication of each respondent's last published paper was 12 months according to the answers received. There was little difference between the seven journals, although the two journals with the fewest articles in 2006 had lower median times.

\section{Submission rejection risk}

According to Table 10, the respondent estimates of the average submission rejection risks were typically concentrated in the $25-50 \%$ and $50-75 \%$ ranges. Construction Innovation was deemed to be the easiest journal to get published in with a clear dominance of answers in the $<25 \%$ and $25-50 \%$ ranges. Building Research and Information attracted the widest spread of estimates, with $16 \%$ of the respondents guessing for less than $25 \%$, while at the other end of the range $11 \%$ guessing at a rejection rate in excess of $90 \%$. Guesses for Construction Management and Economics were highly concentrated in the $50-75 \%$ range. The explanation for this more narrow range might be that $\mathrm{CME}$ has made available on its web pages annual statistics for submissions and published articles; it is thus likely that many authors know that the average CME rejection rate has been around $50 \%$ for a number of years. 
Table 10 Perceived risk of rejection [\% of responding authors]

\begin{tabular}{llllllll}
\hline Submission rejection risk & AIC & BRI & CI & CME & ECAM & IJPM & JCEM \\
\hline Don't know [\% of authors] & 73 & 71 & 79 & 48 & 62 & 54 & 48
\end{tabular}

For those who think they know:

$\begin{array}{llllllll}<25 \% & 17 & 16 & 44 & 8 & 16 & 20 & 6 \\ 25-50 \% & 43 & 21 & 30 & 21 & 49 & 33 & 32 \\ 50-75 \% & 29 & 29 & 19 & 57 & 27 & 35 & 37 \\ 75-90 \% & 11 & 24 & 7 & 14 & 6 & 8 & 18 \\ >90 \% & 0 & 10 & 0 & 0 & 2 & 3 & 7\end{array}$

\section{Journal of latest published article}

Looking at the average values per journal for the five aspects (Service level, Read by researchers, Career value, Review helpfulness, Rejection risk) it emerged that authors tend to hold consistently higher opinions of the journal of their latest published article when compared to aspects of other journals that they are familiar with. This pattern confirms what Gibler and Ziobrowski (2002) found for real estate authors: "[...] a quality journal is unwittingly defined as one that 'publishes my work'."

\section{Ranking of journals for next submission}

Are future publishing priorities among authors to be explained in the same way as their recent history of journal publication? Ordinal logistic regressions (SPSS PLUM) with a logit link function were made to determine relations (per journal) between values on the seven-degree scale for ranking submission priorities and the nine criteria of choice as explanatory variables (Table 11). Note that the dependent variable in Table 11 is journal rank, where the highest figure $(=7)$ denotes the lowest rank, so that a negative coefficient implies a positive effect on ranking. 
Table 11 Ordinal logistic regression: journal ranking for next submission versus general critieria

\begin{tabular}{|c|c|c|c|c|c|c|c|}
\hline \multirow[t]{2}{*}{ Criterion } & \multicolumn{7}{|c|}{ Journal ranked } \\
\hline & AIC & BRI & $\mathrm{CI}$ & $\mathrm{CME}$ & ECAM & IJPM & JCEM \\
\hline $\begin{array}{l}\text { 1. Academic } \\
\text { status }\end{array}$ & $\begin{array}{l}-0.267 \\
(0.270)\end{array}$ & $\begin{array}{l}-0.065 \\
(0.226)\end{array}$ & $\begin{array}{l}0.374 \\
(0.249)\end{array}$ & $\begin{array}{l}-0.014 \\
(0.226)\end{array}$ & $\begin{array}{l}0.097 \\
(0.246)\end{array}$ & $\begin{array}{l}-0.139 \\
(0.234)\end{array}$ & $\begin{array}{l}- \\
0.615 * * \\
(0.243)\end{array}$ \\
\hline $\begin{array}{l}\text { 2. Acceptance } \\
\text { likelihood }\end{array}$ & $\begin{array}{l}0.040 \\
(0.183)\end{array}$ & $\begin{array}{l}-0.143 \\
(0.175)\end{array}$ & $\begin{array}{l}0.080 \\
(0.180)\end{array}$ & $\begin{array}{l}-0.045 \\
(0.168)\end{array}$ & $\begin{array}{l}0.145 \\
(0.178)\end{array}$ & $\begin{array}{l}-0.296^{*} \\
(0.175)\end{array}$ & $\begin{array}{l}-0.307 * \\
(0.094)\end{array}$ \\
\hline $\begin{array}{l}\text { 3. Large } \\
\text { circulation }\end{array}$ & $\begin{array}{l}0.070 \\
(0.207)\end{array}$ & $\begin{array}{l}0.030 \\
(0.192)\end{array}$ & $\begin{array}{l}0.009 \\
(0.209)\end{array}$ & $\begin{array}{l}-0.231 \\
(0.190)\end{array}$ & $\begin{array}{l}- \\
0.444 * * \\
(0.215)\end{array}$ & $\begin{array}{l}0.161 \\
(0.201)\end{array}$ & $\begin{array}{l}- \\
0.418 * * \\
(0.211)\end{array}$ \\
\hline $\begin{array}{l}\text { 4. Relevant } \\
\text { readership }\end{array}$ & $\begin{array}{l}-0.248 \\
(0.236)\end{array}$ & $\begin{array}{l}-0.060 \\
(0.231)\end{array}$ & $\begin{array}{l}0.079 \\
(0.238)\end{array}$ & $\begin{array}{l}0.129 \\
(0.208)\end{array}$ & $\begin{array}{l}0.213 \\
(0.234)\end{array}$ & $\begin{array}{l}0.016 \\
(0.221)\end{array}$ & $\begin{array}{l}0.068 \\
(0.222)\end{array}$ \\
\hline $\begin{array}{l}5 . \quad \text { Time } \\
\text { submission- } \\
\text { publication }\end{array}$ & $\begin{array}{l}0.020 \\
(0.196)\end{array}$ & $\begin{array}{l}0.301 * \\
(0.182)\end{array}$ & $\begin{array}{l}0.111 \\
(0.189)\end{array}$ & $\begin{array}{l}0.010 \\
(0.178)\end{array}$ & $\begin{array}{l}-0.202 \\
(0.185)\end{array}$ & $\begin{array}{l}-0.157 \\
(0.182)\end{array}$ & $\begin{array}{l}0.285 \\
(0.188)\end{array}$ \\
\hline $\begin{array}{l}\text { 6. Articles free } \\
\text { on the Web }\end{array}$ & $\begin{array}{l}0.184 \\
(0.177)\end{array}$ & $\begin{array}{l}-0.057 \\
(0.162)\end{array}$ & $\begin{array}{l}0.097 \\
(0.170)\end{array}$ & $\begin{array}{l}0.299^{*} \\
(0.170)\end{array}$ & $\begin{array}{l}0.253 \\
(0.177)\end{array}$ & $\begin{array}{l}-0.305^{*} \\
(0.176)\end{array}$ & $\begin{array}{l}-0.019 \\
(0.178)\end{array}$ \\
\hline 7. ISI indexed & $\begin{array}{l}-0.331 \\
(0.220)\end{array}$ & $\begin{array}{l}0.008 \\
(0.203)\end{array}$ & $\begin{array}{l}-0.215 \\
(0.213)\end{array}$ & $\begin{array}{l}0.245 \\
(0.203)\end{array}$ & $\begin{array}{l}0.434 * * \\
(0.216)\end{array}$ & $\begin{array}{l}0.188 \\
(0.206)\end{array}$ & $\begin{array}{l}-0.113 \\
(0.223)\end{array}$ \\
\hline $\begin{array}{l}\text { 8. ISI impact } \\
\text { factor }\end{array}$ & $\begin{array}{l}-0.017 \\
(0.238)\end{array}$ & $\begin{array}{l}0.039 \\
(0.224)\end{array}$ & $\begin{array}{l}0.141 \\
(0.230)\end{array}$ & $\begin{array}{l}-0.047 \\
(0.222)\end{array}$ & $\begin{array}{l}-0.030 \\
(0.229)\end{array}$ & $\begin{array}{l}-0.077 \\
(0.218)\end{array}$ & $\begin{array}{l}0.151 \\
(0.240)\end{array}$ \\
\hline $\begin{array}{l}9 . \\
\text { Recommended } \\
\text { journal }\end{array}$ & $\begin{array}{l}0.216 \\
(0.146)\end{array}$ & $\begin{array}{l}0.110 \\
(0.139)\end{array}$ & $\begin{array}{l}0.037 \\
(0.142)\end{array}$ & $\begin{array}{l}-0.089 \\
(0.135)\end{array}$ & $\begin{array}{l}-0.026 \\
(0.139)\end{array}$ & $\begin{array}{l}-0.134 \\
(0.136)\end{array}$ & $\begin{array}{l}0.067 \\
(0.141)\end{array}$ \\
\hline $\begin{array}{l}\text { Nagelkerke's } \\
\text { pseudo-R }\end{array}$ & 0.117 & 0.047 & 0.046 & 0.058 & 0.101 & 0.113 & 0.154 \\
\hline $\mathrm{N}$ & 106 & 107 & 101 & 117 & 104 & 106 & 113 \\
\hline
\end{tabular}

Standard deviations in parentheses. Dependent variables: journal rank 1-7 (1= highest rank, 7 $=$ lowest $)$; independent variables with $1-5$ scales $(1=$ low, $5=$ high $) . *$ significant on the 0.10 level, $* *=$ significant on the 0.05 level, $* * *$ significant on the 0.01 level.

The low values for Nagelkerke's pseudo multiple correlation coefficient show that actual ranking of journals is difficult to predict from individual criteria values. Nevertheless, taking into account the significant coefficients in Table 11, it can be seen that six criteria affect author choice of where to submit new manuscripts. There is no consistent effect of criteria such as academic status and ISI indexation, which means that career motives appear to be weak. The criteria that do not make a significant difference for any journal are relevant 
readership (which received a high average score in Table 5), ISI impact factor and being a recommended journal.

\section{Conclusions}

The survey results show that researchers who publish scientific articles in the field of construction management do not differ markedly from academic authors in general. They do read slightly fewer articles, and they are little concerned with the level of journal impact factors. Much like in other fields they enjoy being read by a narrow circle of peers. Scientific publishing fills an important role as a reasonably neutral and global system of talent assessment that influences decisions on promotion and tenure in many university cultures. However, it is clear that career prospects are far from the only source of motivation for construction management authors. Many authors are unaware of a range of characteristics for journals where they have not been published before, which indicates that there are subcommunities whose members share a sense of belonging to a particular journal within the construction management field. At present, construction management authors rely on open access publishing to about the same extent as authors in other academic fields.

The analysis performed here shows that it is feasible to detect profiles of construction management journals that could be used as a broader base for benchmarking from the viewpoint of authors. A few characteristics of these journals were found to be insignificant in the choice situation, as in the case of author perceptions of relevant readership. From responses to background questions in the questionnaire, it is also possible to see that there is little actual difference in median processing times for manuscripts, a criterion which also carried little weight in the reported journal ranking for next submission of a manuscript. Findings like these should also be helpful for journal publishers and editors who wish to make their journals more attractive as outlets for research in the field.

It is important to distinguish between journal quality, journal impact as measured by article citations and journal visibility interpreted as researcher familiarity with a particular journal (Olson, 2005). From our analysis a cluster of three journals emerges (CME, IJPM and JCEM). These three have high visibility and are regularly followed by at least half the respondents, which also could indicate that they have personal subscriptions or institutionally paid access to them. Unfortunately only one of these (JCEM) is indexed in the Science Citations Index, which makes citations based comparisons of impact difficult. The other four journals receive lower scores on readership as well as on some of the other perceived characteristics.

Many prospective authors confess ignorance of how a range of journals perform in respects that appear to be important for journal choice. It is not only the price issue that is affected by ignorance. Publishers and editors should consider making known more of what is of importance to readers; the present lack of transparency is unlikely to promote efficiency, however measured.

Although the response rate is high for this type of e-mail survey, bias in favour of e-mail readers is probably something that has to be kept in mind when interpreting the results. Thus our responses might overstate the proportion of authors who actually post their manuscripts or published texts on the web. On the other hand, and causing a slight surprise, there is no fundamental difference in the worldview of authors who post on the web and those who do not.

Just like the present investigation asks new questions from the authorial perspective, rather than attempting to follow the established tradition of academic quality ranking, there is a wider issue of how the contents of these journals relates to the development of construction 
practice. Another approach is also needed to study when and why these journals are cited and used by authors contributing to built environment journals in general, as well as by those who publish in mainstream management journals. Moreover, too little is known about the strategies authors follow when they wish to exert a strong influence on the development of theory in the field of construction management; the choices they make in that perspective, whether to submit an article to a particular journal, to write a monographs, book chapters or to emphasize the medium of scientific symposia have not been analysed.

\section{References}

Adeli, H. (2007) Measuring research journals (editorial). Computer-Aided Civil and Infrastructure Engineering, 22(1), 1-5.

Bence, V. and Oppenheim, C. (2005) The evolution of the UK's Research Assessment Exercise: publications, performance and perceptions. Journal of Educational Administration and History, 37(2), 137-55.

Bergstrom, C.T. and Bergstrom, T.C. (2006) The economics of ecology journals. Frontiers in Ecology and the Environment, 4(9), 488-95.

Betts, M. and Lansley, P. (1993) Construction Management and Economics: A review of the first ten years. Construction Management and Economics, 11(4), 221-245.

Betts, M. and Lansley, P. (1995) International Journal of Project Management: a review of the first ten years. International Journal of Project Management, 13(4), 207-217.

Björk, B.-C. and Holmström, J. (2006) Benchmarking scientific journals from the submitting author's viewpoint. Learned Publishing, 19(2), 147-155, available at http://www.ingentaconnect.com/content/alpsp/lp/2006/00000019/00000002/art00009 (accessed 4 June 2007).

Björk, B.-C. and Turk, Ž. (2000) How scientists retrieve publications: an empirical study of how the Internet is overtaking paper media. Journal of Electronic Publishing, 6(2), available at www.press.umich.edu/jep/06-02/bjork.html (accessed 25 May 2007).

Björk, B.-C., Turk, Ž. and Holmström, J. (2005) The scholarly journal re-engineered: a case study of an open access journal in construction IT. Electronic Journal of Information Technology in Construction, ITcon, 10, 349-371, available at www.itcon.org (accessed 25 May 2007).

Chau, K.W. (1997) The ranking of construction management journals. Construction Management and Economics, 15(4), 387-398.

Chesler, A. (2006) Core issues in pricing models for scholarly journals: a qualitative overview. Learned Publishing, 19(2), 142-46.

Crane, D. (1972) Invisible colleges: diffusion of knowledge in scientific communities, University of Chicago Press, Chicago.

de Marchi, M. and Rocchi, M. (2001) The editorial policies of scientific journals. Scientometrics, 51(2), 395-404. 
Geary, J., Marriott, L. and Rowlinson, M. (2004) Journal rankings in business and management and the 2001 Research Assessment Exercise in the UK. British Journal of Management, 15(2), 95-141.

Gibler, K.M. and Ziobrowski, A.J. (2002) Authors' perceptions and preferences among real estate journals. Real Estate Economics, 30(1), 137-57.

Herron, T.L. and Hall, T.W. (2004) Faculty perceptions of journals: quality and publishing feasibility. Journal of Accounting Education, 22(3), 175-210.

Hertel, G., Niedner, S. and Herrmann, S. (2003) Motivation of software developers in open source projects: an Internet-based survey of contributors to the Linux kernel. Research Policy, 32(7), 1159-77.

Hicks, D. (1999) The difficulty of achieving full coverage of international social science literature and the bibliometric consequences. Scientometrics, 44(2), 193-215.

JISC (2004) JISC/OSI Journal Authors Survey Report, prepared by Key Perspectives, Joint Information Systems Committee, available at www.jisc.ac.uk/uploaded_documents/ACF655.pdf (accessed 25 May 2007).

Kyvik, S. (2003) Changing trends in publishing behaviour among university faculty, 19802000. Scientometrics, 58(1), 35-48.

Lerner, J. and Tirole, J. (2002) Some simple economics of open source. Journal of Industrial Economics, 50(2), 197-234.

Lerner, J. and Tirole, J. (2005) The economics of technology sharing: open source and beyond. Journal of Economic Perspectives, 19(2), 99-120.

Leslie, D. (2005) Are delays in academic publishing necessary? American Economic Review, 95(1), 407-13.

McGrail, M.R., Rickard, C.M. and Jones, R. (2006) Publish or perish: a systematic review of interventions to increase academic publication rates. Higher Education Research and Development, 25(1), 19-35.

McKnight, C. and Price, S. (1999) A survey of author attitudes and skills in relation to article publishing in paper and electronic journals. Journal of Documentation, 55(5), 556-76.

Olson, J.E. (2005) Top-25 Business School Professors Rate Journals in Operations Management and Related Fields. Interfaces, 35(4), 323-38.

Pietroforte, R. and Aboulezz, M.A. (2005) ASCE Journal of Management in Engineering: Review of the years 1985-2002. Journal of Management in Engineering, 21(3), 125-30.

Pietroforte, R. and Stefani, T.P. (2004) ASCE Journal of Construction Engineering and Management: Review of the years 1983-2000. Journal of Construction Engineering and Management, 130(3), 440-48.

Schroer, J. and Hertel, G. (2007) Voluntary engagement in an open web-based encyclopedia: Wikipedians, and why they do it. Working Paper, University of Wuerzburg.

Schroter, S., Tite, L. and Smith, R. (2005) Perceptions of open access publishing: interviews with journal authors. British Medical Journal, 330(7494), 756-59. 
Steele, C., Butler, L. and Kingsley, D. (2006) The publishing imperative: the pervasive influence of publication metrics. Learned Publishing, 19(4), 277-90.

Tenopir, C. and King D.W. (2000) Towards Electronic Journals: Realities for Scientists, Librarians, and Publishers. Special Libraries Association, Washington, D.C.

Ziobrowski, A.J. and Gibler, K.M. (2000) Factors academic authors consider when choosing where to submit a manuscript for publication. Journal of Real Estate Practice and Education, 3(1), 43-54. 